\title{
Percepciones, imágenes y opiniones sobre la vejez desde la mirada de los adultos y jóvenes en México
}

\section{Perceptions, images and opinions of the old age from the perspective of adult and young people in México}

doi: https://doi.org/

10.32870/eees.v26i75.7024

\section{Resumen}

Este artículo presenta los resultados de una investigación cuyo objetivo es explorar las percepciones, imágenes y opiniones sobre la vejez entre la población de dieciocho a cincuenta y nueve años en México. Para ello, se revisa la Encuesta Nacional de Envejecimiento realizada por la Universidad Nacional Autónoma de México en 2015.Los resultados muestran, de manera general, que las imágenes y percepciones del envejecimiento en dicha población se basan en la visión de una etapa de la vida y no de un proceso. De manera particular, la investigación demuestra que dicha etapa es pensada y definida a través de las debilidades físicas y las pérdidas, conjuntadas con opiniones contradictorias sobre el papel de la familia y el Estado en los cuidados especiales que se requieren y el reconocimiento de los derechos de las personas mayores.

Palabras clave: envejecimiento, percepciones sociales, imágenes sociales, jóvenes, México.

\author{
Paola Carmina Gutiérrez Cuéllar`
}

\begin{abstract}
This article presents the results of a research that looked for explore the perceptions, images and opinions about old age in the population between eighteen and fifty-nine years old in Mexico. For that porpoise, the Encuesta Nacional de Envejecimiento, made by the Universidad Nacional Autónoma de México at 2015, is reviewed.The results show, in general, that images and perceptions define old age as a stage and not as a process. Particularly, the research shows that that stage is thought as weaknesses and losses, which are combined with contradictory opinions about the families and state intervention to give palliative care, and the recognition of some rights of older persons.
\end{abstract}

Keywords: Aging, social perceptions, social images, young people, Mexico.

\footnotetext{
- Investigadora posdoctorante en el Instituto de Investigaciones Sociales (IIS) de la Universidad Nacional Autónoma de México (UNAM), México. ORCID:https://orcid.org/0000-0003-0063-5658 paola.carmina1721@gmail.com

Fecha de recepción: 26 de enero de 2018. Fecha de aceptación: 08 de marzo de 2019.
} 
Introducción'

De acuerdo con datos de la Encuesta Intercensal del Instituto Nacional de Estadística y Geografía (INEGI), en 2015 México contaba con poco más de 8.5 millones de personas de sesenta y cinco años y más (el $7.15 \%$ de la población total) (Instituto Nacional de Estadística y Geografía, 2015). Las estimaciones mundiales ubican a esta nación como parte de los países en desarrollo que han comenzado un rápido proceso de envejecimiento poblacional, de forma que para el 2050 los mexicanos mayores de sesenta y cinco años habrán rebasado el 20\% de la población (Consejo Nacional de Población, 2011). Derivadas de estas dinámicas poblacionales, las principales acciones por parte de los Gobiernos nacionales se han ocupado de las implicaciones en los sistemas de pensiones y atención de la salud, aunque las áreas involucradas deberían ser muchas más.

En cuanto a las condiciones económicas, el Centro Latinoamericano de Población, de la Comisión Económica para América Latina y el Caribe (CEPAL), calcula que más del 30\% de las personas mayores de sesenta y cinco años en América Latina vive en condiciones de pobreza. Más del 60\% de esa población se provee de las ayudas familiares, por lo que sus ingresos propios son muy reducidos; la gran mayoría de las mujeres adultas mayores no cuenta con ingresos de una pensión propia por no haber laborado en su etapa productiva en un empleo formal, lo que coloca a dichas mujeres en una condición aún más desfavorable (Huenchuan, 2006).

En cuanto a las condiciones físicas de dicha población, es indudable que esta etapa de la vida se relaciona con declives del cuerpo muy importantes: según el Censo de Población

I. La autora agradece al Programa de Becas Posdoctorales de la Coordinación de Humanidades y al Instituto de Investigaciones Sociales de la Universidad Nacional Autónoma de México (UNAM), así como a la doctora Verónica Montes de Oca por su apoyo para la realización de esta investigación. 
y Vivienda de 2010 en México, un 20\% de los adultos de sesenta a ochenta y cuatro años contaba con alguna limitación física, mientras que este porcentaje aumentaba en edades superiores a los ochenta y cinco años (59\%) (Instituto Nacional de Estadística y Geografía, 2010).

A pesar de las condiciones de pobreza, únicamente el $32 \%$ de las personas mayores en México recibe algún apoyo de los programas de Gobierno como ayuda alimentaria o de salud. La gran mayoría de ellas son derechohabientes de los sistemas de seguridad social, sobre todo del Instituto Mexicano del Seguro Social (IMSS) (43\%) (Instituto Nacional de Estadística y Geografía, 2015). Además, una parte de las personas mayores vive en sistemas familiares muchas veces discriminatorios y que ejercen diversas formas de maltrato de las que aún se desconoce mucho y que apenas se han comenzado a estudiar (Giraldo, 2006).

En los resultados de la Encuesta Nacional sobre Discriminación (ENADIS) de 2010, el 30\% de las personas mayores señaló haber sufrido violaciones a sus derechos por razones vinculadas a su edad, y el $90 \%$ haber sufrido discriminación por la misma razón al solicitar algún empleo (Consejo Nacional para Prevenir la Discriminación, 2010).

Además de la falta de espacios para el empleo, las personas mayores consideran que sus principales problemas como grupo etario son las condiciones de salud y discapacidad, seguidas de los maltratos y acciones discriminatorias en su contra ejercidos por la sociedad en general y el Gobierno (Montes de Oca, 2013, p. 21). Al menos el 58\% de ellas atribuye al desconocimiento de sus problemas la falta de ayuda por parte de la sociedad en general, según la ya mencionada ENADIS de 2010 (Consejo Nacional para Prevenir la Discriminación, 2010).

Todo esto hace que genere sentido preguntar: ¿existen estereotipos y percepciones negativas de la vejez y las per- 
sonas mayores entre la población que no pertenece a ese grupo de edad, y que influyen en el trato que esta les da?

Algunas pruebas psicológicas que contrastan los estereotipos sobre la vejez en personas mayores y en jóvenes muestran que estas percepciones negativas de los otros influyen ampliamente en lo que las personas mayores piensan de sí mismas, de tal forma que incluso toman decisiones de vida basadas en ellas y pueden sentirse más o menos anclados a sus comunidades y sociedades dependiendo de dichas percepciones (Levy, Ashman, y Dror, 2000; Fernández y Herrero, 2006; Dionigi, 2015).

Dada esta importancia, el objetivo de la investigación es explorar las percepciones y opiniones sobre la vejez y las personas mayores en la población que aún no envejece en México, con la finalidad de evidenciar la ausencia de conocimiento sobre dicha etapa de vida y sobre las personas mayores, así como la visión estereotipada que existe de las mismas. Para ello, se utilizan datos recopilados en la Encuesta Nacional de Envejecimiento (ENE) durante 2014 y publicados en 2015 .

Se verá que las imágenes sociales de la vejez presentan diversas contradicciones entre estereotipos y visiones flexibles sobre ella y sobre las personas mayores. El estudio del que emana la presente investigación se enmarca en un contexto de vida urbano, lo que plantea grandes diferencias respecto al ámbito rural o semirural, por lo que no se pretende generalizar ni plantear que lo aquí presentado sea representativo de todos los contextos del país, pues de acuerdo con los diferentes componentes culturales, las personas mayores ocupan posiciones sociales distintas que a su vez promueven tratos diferentes hacia ellas.

El artículo presenta, en primer lugar, algunas propuestas teóricas y conceptuales sobre las representaciones y percepciones sociales con la intención de que sirvan de referente para la exploración de las realidades mexicanas 
en torno a la vejez. En segundo lugar, se muestran algunos estudios previos realizados a nivel nacional e internacional al respecto del fenómeno analizado. En tercer lugar, se presentan las percepciones e imágenes de los jóvenes y adultos sobre la vejez, las personas mayores y las responsabilidades sociales en torno a ellas en México. Finalmente, se ofrecen algunas conclusiones reflexivas alrededor de los estereotipos y representaciones en la población no envejecida y sus implicaciones en las problemáticas vinculadas al proceso de envejecimiento en el país.

\section{Representaciones, percepciones e imágenes sociales}

La teoría sobre las representaciones sociales hace referencia a las imágenes, símbolos y estructuras mentales a partir de las cuales se conforma un conocimiento de la vida cotidiana que permite las relaciones entre los seres humanos. En el caso concreto de este estudio, permite las relaciones de los sujetos sociales con la vejez y las personas adultas mayores.

Representar implica otorgar una función y lugar social a un objeto, persona o relación; es darle un significado y una categoría. Desde la psicología social, se desarrolla el concepto de representaciones para resaltar la conformación de los seres humanos como individuos contextualizados por sus ambientes sociales, culturales y colectivos, que influyen en sus acciones individuales (Mora, 2002).

Uno de los principales exponentes de la teoría de las representaciones sociales, Serge Moscovici (2000), propone una reflexión sobre las representaciones y sus compuestos, y considera que las representaciones sociales se componen de actitudes, opiniones, imágenes y estereotipos que se construyen y combinan para permitir que se tengan ideas sobre cómo actuar frente a los demás. 
En concreto, las actitudes permiten otorgar una orientación positiva o negativa a la representación social, mientras las opiniones fijan las posiciones de los individuos al respecto de lo que se observa, y los estereotipos conforman atributos específicos y rígidos de un grupo dados por ciertas características. Las imágenes son fotografías llenas de significados que dan sentido a las cosas, situaciones y personas. Luego entonces, las representaciones sociales son construidas por la interacción, las condiciones y los valores e ideas culturales vigentes en una sociedad.

La escuela de Chicago, al rescatar la importancia de la interacción, la cultura y las costumbres en el funcionamiento de las sociedades, fue la que desarrolló una corriente de estudio denominada interaccionismo simbólico, a partir de la cual se dio forma al estudio de las representaciones sociales. Como parte de esta corriente, John Dewey y George $\mathrm{H}$. Mead estudiaron los elementos que influyen en las acciones y decisiones de los individuos en sociedad, y mostraron que el individuo se forma de sus interacciones con los otros, al mismo tiempo que aporta a la formación de los otros. En este proceso de interacción, hay símbolos determinados por el lenguaje (oral, gestual y corporal) que tienen significados válidos en ese espacio de interacción, por ejemplo, en un salón de belleza o en el transporte público, a partir de los cuales se configuran reglas y formas de trato informales que guían las acciones de todos los que participan en ese mismo espacio (Mead, 1982).

Por su parte, Cornellius Castoriadis (1997), desde la filosofía y la psicología social, estudió los imaginarios sociales para referirse a los modos de pertenencia, normas $y$ asignaciones de significado que se tejen entre los seres humanos y que permiten la interacción social. Nótese que no se trata de una imagen o representación individual, sino de aquella que se forma a partir de lo que la generalidad 
de una comunidad social entiende al respecto de su mundo $\mathrm{y}$ sus integrantes.

A su vez, para reflexionar en torno a las modernidades, Charles Taylor (2006) habla sobre los imaginarios sociales y señala que se tratan de los elementos sociales que permiten comprender la propia existencia y la de los demás, por lo que implican imágenes y percepciones de lo normal, lo no normal, los comportamientos y las formas de actuar de cada persona de acuerdo con ciertas características como ser mujer u hombre, profesionista o joven. Son una línea básica de entendimiento en un mundo cada vez más diverso.

En cierta medida, las representaciones e imaginarios sociales implican un tipo de conocimiento que permite tomar decisiones, y que, no siendo especializado ni científico, se denominará conocimiento del sentido común. Con él, se dirige la mayor parte de la vida y este se aprende desde la niñez dentro de los procesos de socialización, por lo que no suele haber conciencia sobre él. Por esta razón, para estudiosos como Moscovici, las representaciones sociales implican "una modalidad particular de conocimiento, cuya función es la elaboración de los comportamientos y la comunicación entre los individuos" (Moscovici, 2000, p. 18), y que está compuesta por símbolos y figuras que se corresponden y forman pensamientos sociales.

Estas imágenes de lo que somos y son los demás se construyen y transmiten a partir de leyendas, historias, mitos, estereotipos, prejuicios y tradiciones que promueven la difusión del conocimiento social. Es decir, se pueden recuperar y recopilar a partir de la tradición oral, los discursos, las historias escritas en diversos géneros o en el discurso científico sobre los fenómenos, y por generaciones, tipos de sociedades o etapas del desarrollo humano. 


\section{Significados e imaginarios de la edad, la vejez} y el envejecimiento en diversos estudios

Como se dijo antes, el propósito de este artículo es observar algunas de las imágenes y representaciones sobre la vejez y el proceso de envejecimiento en la población que aún no llega a dicha etapa de vida. Se trata, pues, de la exploración de lo que son los otros diferenciados por la edad cronológica y socialmente conceptualizada, que, si bien no es la realidad más precisa, sí enmarca las formas en que la población trata y se comporta frente a las personas mayores, y en ese sentido, también permite ver cómo se forman las actitudes discriminatorias y el maltrato hacia dicho grupo poblacional.

Se observarán las apreciaciones que hace la población adulta y joven (entre dieciocho y cincuenta y nueve años de edad) ${ }^{2}$ sobre la vejez y las personas mayores para conformar una primera construcción de lo que se piensa que es vivir en esta etapa, qué características la definen y cómo creen los mexicanos que se comporta dicho grupo etario.

Esta exploración es relevante en varios sentidos. Por un lado, el acelerado proceso de envejecimiento en México ha manifestado cambios y tensiones no sólo económicos, sino también sociales y familiares que han modificado el lugar de los mayores en los espacios sociales. Por otro lado, este acelerado proceso de envejecimiento indica también una nueva etapa de la sociedad en cuanto a cuestiones culturales y psicológicas: debido a que las poblaciones deben adaptarse a una mayor expectativa de vida, estas también deben ver y tratar a personas más longevas, con características para las que no estaban preparadas: "Los cambios demográficos

2. Se considera este rango de edad debido a que la CEPAL ubica el inicio de la vejez para la mayoría de los países de la región latinoamericana a los sesenta años, es decir, los Gobiernos dirigen políticas públicas y atención a las personas mayores considerando de inicio esa edad (Comisión Económica para América Latina y el Caribe, 20II).

\section{4}


traen consigo cambios asociados a la edad, que atañen a la percepción que las personas tienen de sí mismas, a la valoración que los demás les asignan y el papel que desempeñan en su comunidad" (Villa y Rivadeneira, 2000, p. 25).

Dicho en otras palabras, diversos estudios apuntan lo acelerado del proceso de envejecimiento poblacional en países desarrollados, y manifiestan la existencia de una tensión social en el tratamiento de los cambios económicos y de salud, pero también en las dinámicas familiares, de parentesco y de pareja, las cuales pasan por la forma en cómo la población piensa y se relaciona con el envejecimiento y sus condiciones, ya sea en dicha etapa de vida o desde su juventud y adultez (Anderson y Hussey, 2000).

Por otro lado, y desde una perspectiva más individualista, algunos estudios sobre las condiciones de vida de las personas mayores muestran que los lazos sociales y familiares son una variable fundamental en su calidad de vida, e incluso son más valorados por ellas que las condiciones de salud que puedan tener en dicha etapa de vida. Además de dichos lazos, las personas mayores valoran el bienestar emocional y la espiritualidad (Rojo y Fernández, 2011, p. 103).

Relacionado con lo anterior, también se ha encontrado que el entorno urbano y social influye en la calidad de vida de las personas mayores. En un estudio en España sobre las dimensiones de la calidad de vida de las personas mayores y su influencia en las percepciones de sus condiciones socioeconómicas, Vicente Rodríguez et al. (2011) encontraron que los significados sobre los recursos económicos son relativos y no dependen sólo del monto o la capacidad adquisitiva, sino también de otros factores como las relaciones sociales y los lazos familiares, de manera que aunque los ingresos monetarios de las personas mayores sean bajos, estas pueden sentir mayor bienestar si tienen lazos socio-familiares fuertes. La variable del nivel educativo también hace 
una diferencia en sus percepciones: a mayor nivel educativo, mayor percepción del bienestar.

Por todo esto, es posible decir que los lazos sociales y familiares son elementos que se nutren de las perspectivas e imágenes que tiene la población sobre el envejecimiento y que provienen de una construcción social e histórica alimentada de valores y preceptos culturales, discursos políticos y sociales, posiciones de los medios de comunicación, y la mercadotecnia.

Mención aparte merece en el caso de México uno de los fenómenos que se ha hecho evidente en el estudio del envejecimiento poblacional: el maltrato y abuso que viven una buena parte de las personas mayores. Diversos trabajos han documentado los abusos físicos, psicológicos, económicos y sexuales que sufre dicho grupo poblacional por parte de familiares y amigos, actores del sector médico e institucional, y programas públicos y privados (Montes de Oca, 2010; Giraldo, 2006; Giurani y Hasan, 2000). Estos fenómenos también impactan lo que se considera que es la vejez y la vida de los mayores.

Estos malos tratos y abusos se agravan por otras condiciones, como ser mujer. Además de que la mayor parte de la población envejecida en México pertenece al género femenino, se documenta que las mujeres continúan viviendo malos tratos por parte de hijos y familiares cuando el cónyuge ha muerto, por ejemplo (Giraldo, 2010). Entre las causas de dicha violencia, se encuentran las nuevas dinámicas familiares, económicas y de empleo en México y varios países en desarrollo, que limitan las oportunidades de apoyo familiar y social para las personas adultas mayores, demeritan su calidad de vida y propician dinámicas de maltrato y abandono cada vez más frecuentes contra ellas, sobre todo en la medida en que sus necesidades los convierten en personas cada vez más dependientes de otros (Tamez y Ribeiro, 2014).

\section{6}


Percepciones, imágenes y opiniones sobre la vejez desde la mirada de los adultos y jóvenes en México

En la ENADIS realizada en 2005 (Consejo Nacional para Prevenir la Discriminación, 2005), se constata que en la opinión de la población en general (40\%), y también en la de las personas mayores en concreto, ${ }^{3}$ el grupo de sesenta años y más resulta el más desamparado. Por tipos de discriminación, se consideraba entonces que la más habitual era la discriminación en el empleo, pues cerca de la mitad de los encuestados consideró que los adultos mayores enfrentaban más dificultades para conseguir empleo por su edad.

Además, se tiene la percepción de que también en los sistemas de salud los adultos mayores enfrentan tratos diferenciados por su edad, y si además son pobres y mujeres pueden enfrentarse a la total invisibilidad social, por lo que se nota que las condiciones de discriminación no están aisladas, sino que son acumulativas (Ham y González, 2008).

Por su parte, los principales resultados de la ENADIS realizada en 2010 muestran tendencias similares: sólo el 33\% de los mexicanos considera que se respetan mucho los derechos de los adultos mayores, un 60\% considera que los adultos mayores enfrentan discriminación en el trabajo por edad, y el mismo porcentaje de los adultos mayores manifiesta dificultades para encontrar trabajo por su edad (Consejo Nacional para Prevenir la Discriminación, 2010).

Maltratos, abusos, discriminación y descuidos, todas son problemáticas que apuntan al desconocimiento social de lo que pasa con la edad como población y como individuos, de lo que significa e implica llegar a ser viejo, de lo que sociedad

3. En este artículo, se utiliza el concepto personas mayores por ser de uso más reciente y permitir evitar conceptos negativos -y hasta contradictorios, como el de adultos mayores-. El concepto de personas mayores se utiliza a partir de la Convención Interamericana sobre la Protección de los Derechos Humanos de las Personas Mayores, del 20I5. No obstante, cuando en el curso del artículo se hace mención a otras etiquetas, como adultos mayores, la utilización corresponde a su manejo en encuestas y documentos analizados, y no al tratamiento específico elegido para este material. 
y Estado deben hacer para que todas las poblaciones vivan en sus nuevas condiciones demográficas.

Finalmente, lo que socialmente se piensa y percibe respecto de la vejez, el proceso de envejecimiento y las personas mayores también se va plasmando en las decisiones públicas, los programas, las políticas y las estrategias de acción para apoyar a esta población, es decir, los contenidos, enfoques y alcances de dichas planeaciones son definidos por el papel social que se le da a esta etapa de la vida y a quienes la viven. Por ello, cuestionar las representaciones y percepciones sociales del envejecimiento y la vejez cobra un sentido social muy importante.

Algunos estudios pioneros en el campo de la sociología sobre las percepciones e imaginarios de los procesos de envejecimiento fueron desarrollados en la década de los cincuenta en Estados Unidos por la ya mencionada escuela de Chicago, que sostiene la existencia de una parte no estructural y tampoco institucional en las sociedades, y que destaca la necesidad de estudiar los procesos culturales, psicosociales y la interacción social para comprender mejor fenómenos y procesos, resultados y situaciones del diario devenir. Inicialmente se trataba de estudios derivados de los egresados de la División de Estudios Sociales de la Universidad de Chicago, quienes comenzaron por el análisis de las condiciones de la población infantil hasta llegar al análisis de la población adulta y adulta mayor, y articularon un equipo de estudios del desarrollo humano interdisciplinario. Un miembro angular del grupo fue Bernice L. Neugarten, quien planteó el estudio de los significados de la edad para encontrar cómo inciden estos en las relaciones sociales (Neugarten, 1999).

A través de sus estudios, Neugarten (1999) ha hecho evidente que la edad no es sólo una condición biológica y física del cuerpo humano, sino que socialmente se han ido construyendo características y formas de actuar y pensar

\section{8}


respecto a cada etapa de la vida, aunque estas sean marcadas inicialmente por las características biológicas. Así, la investigadora fue desarrollando estudios sobre las formas en que la edad es socialmente construida y marcada por las representaciones de lo que es normal o usual hacer, pensar y actuar en ella, por lo que, por ejemplo, hay un tiempo para ser padre, y otros para ser estudiante, abuelo o jubilado. Es decir, existe un tiempo social, definido por el conjunto de los seres humanos que interactúan en un mismo contexto, y que va modificándose conforme suceden los grandes cambios económicos, sociales o culturales en las sociedades.

En uno de sus estudios, Neugarten, Moore y Lowe (1999) encuestaron a hombres y mujeres, adultos y personas mayores de una comunidad de Estados Unidos, y encontraron construcciones sobre las actividades, acciones, decisiones y características consideradas más adecuadas para cada grupo de edad. Por ejemplo, para las personas mayores, el matrimonio entre una pareja cuyos elementos tuvieran diecisiete años de edad era visto como una locura, dados los problemas a los que se suelen enfrentar las parejas casadas, pero para un adulto de veinticinco años ese mismo matrimonio era visto como una buena decisión si sus integrantes al menos tenían condiciones materiales para sobrevivir.

Estos estudios, y varios otros, han mostrado cómo cada individuo guía su interacción con los demás por medio de lo que considera que son los otros, es decir, de cómo se representa a los otros a partir de sus condiciones, una de las más evidentes la edad física y biológica. Dicho de otro modo, de acuerdo con la edad, el género y varias otras características, las personas generan imágenes y representaciones de cómo son los otros, qué hacen, qué necesitan o cómo deciden.

Otros estudiosos del tema se han preguntado por las construcciones sociales de la vejez como una categoría de análisis social que resurge, en primera instancia, por el aumento de la esperanza de vida que recompone la interacción social 
con un grupo de edad que solía tener poca interacción por su corta estadía en las sociedades. A partir de los avances científicos y médicos, la vida se prolonga y las condiciones económicas y sociales mejoran en la mayoría de las sociedades modernas. Por ello, este grupo etario se localiza en una posición más activa en tanto está más presente en las sociedades.

Kehl y Fernández (2001) realizan un recorrido por los estudios y teorías sociales (de la sociología y la psicología social) que se encargan de estudiar el envejecimiento de la población, para encontrar que la vejez como una etapa de la vida humana es una construcción social que se va modificando conforme cambian las sociedades, y en específico las condiciones sociales y económicas de las mismas. Existe, pues, una valoración de elementos que ponen a los sujetos en cierto lugar de acuerdo con roles social e históricamente construidos, los cuales, en el caso de las sociedades occidentales, están basados en la productividad, la eficiencia y la utilidad (Rice, Löckenhoff, y Carstensen, 2002). La percepción de que la etapa de la vejez comienza con la jubilación de las actividades laborales refuerza las ideas de improductividad en torno a dicha etapa etaria, y al mismo tiempo impone discriminaciones determinadas por otros factores como la pobreza, una condición socioeconómica a la que pasan muchas personas mayores desde el momento en que deben jubilarse y sobrevivir con sistemas de pensiones insuficientes, lo que sucede en los países en desarrollo.

Aunque de acuerdo con las condiciones de cada sociedad los significados de la vejez se modifican, los autores encuentran que no hay época en la que las concepciones de la vejez muestren aspectos positivos y apreciados por el resto de los miembros, esto al menos en las sociedades occidentales (Kehl y Fernández, 2001). Sin embargo, probablemente después de un siglo de desarrollo de las sociedades industriales y posmodernas, las percepciones 
de la vejez se estén modificando, pues en muchas de las sociedades desarrolladas, como Japón y Noruega, el grupo etario de personas mayores constituye ya casi un tercio de sus poblaciones y sigue colaborando con el movimiento de la economía (Muramatsu y Akiyama, 2011), mientras en los países en desarrollo son un grupo en crecimiento que también colabora con la reproducción social y con un trabajo no remunerado pero sustancial, como es el cuidado de los nietos o familiares enfermos, cocinar para la familia o compartir su vivienda. Por todo esto, es de esperarse que la población que aún no envejece esté construyendo percepciones más inclusivas y positivas sobre la vejez.

Para Moñivas (1998, p. 20), desde inicios del presente siglo hay cambios significativos en la forma de tratar el envejecimiento desde el ámbito de la salud que evitan que sea asociado a la enfermedad y hacen que se destaque la adaptabilidad de cada etapa de la vida. Además, se comienza a observar que cada etapa debe ser valorada en sí misma y no en comparación con otras, que todas tienen un lugar en el ciclo vital, y que su tratamiento y estudio necesitan de una visión psicosocial y no únicamente médica y biológica.

Para abonar a esta misma postura, hay que señalar que Gergen y Gergen (2000) estudian los cambios en las construcciones y valores que corresponden a la vejez en las sociedades contemporáneas, sobre todo en países desarrollados, y muestran que se ha pasado de una percepción de vida agreste y de pérdidas vinculada con dicha etapa (pérdida del trabajo, la pareja, los hijos, etc.) a una en la que las personas mayores son una población cada vez más importante, productiva y activa.

Las causas de estos cambios en las percepciones sobre la vejez, según los propios autores, están en las modificaciones demográficas, en concreto el aumento en la cantidad de personas mayores de sesenta años, así como en las condiciones de vida como mejores ingresos y sistemas de pensiones, 
medicamentos y tratamientos médicos para padecimientos físicos y mentales. También, debe señalarse el empoderamiento de las personas mayores, que ahora se definen a sí mismas como fuertes y activas, que viven una etapa de la vida sin hijos que cuidar o hipotecas que pagar, y en la que también viajan y enfrentan enfermedades.

A su vez, al buscar explorar la mirada de los jóvenes hacia la vejez en Chile, un grupo de académicos de la Universidad de Chile realizó un estudio de tipo semántico a seiscientos ochenta y dos estudiantes universitarios para determinar cómo son percibidas las personas mayores por dicho grupo. Sometidos a una prueba en la que se definen primero dicotomías de palabras que se refieren y se asocian a las personas mayores, tales como improductivo-productivo, integrado-marginado y otras, el estudio mostró que predominan imágenes negativas que afectan las perspectivas sobre la población mayor: las personas mayores son vistas como dependientes, enfermizas, ineficientes, frágiles y desamparadas (Cathalifaud, Thumala, Urquiza, y Ojeda, 2007).

En términos de algunos roles sociales, el mismo estudio observó que los jóvenes consideran que las personas mayores son más ciudadanos pasivos que activos, y en términos económicos las percibieron como personas poco productivas. Algunos de estos resultados se diferenciaron por el género, otorgando la idea de mayor enfermedad y debilidad a los hombres que a las mujeres (Cathalifaud, Thumala, Urquiza, y Ojeda, 2007).

Ahora bien, en México se han explorado las percepciones sobre la vejez desde diferentes puntos de vista, sobre todo respecto a las que se forman los propios adultos mayores. A partir de un estudio intergeneracional que analiza discursos para observar la conformación de uno mismo y de los otros (Ronzón, 2014), se ha mostrado que las percepciones en el país varían de acuerdo con la edad y si el sujeto se encuentra en la etapa de la vejez o no.

\section{2}


Según reporta Ronzón (2014), para las personas mayores en México la vejez representa un parteaguas: señalan que antes -en su vida- podían caminar mejor, tenían menos enfermedades y necesitaban menos de los otros. Por otro lado, para las generaciones jóvenes y adultas, la vejez está marcada principalmente por debilidades y dificultades físicas, y aunque en el discurso se encuentra el reconocimiento a mayores cuidados y atenciones, todavía no llegan a ser parte de las prácticas familiares y gubernamentales (Ronzón, 2014).

El avance de los estudios en la temática muestra que la observación de las construcciones e imaginarios de la vejez conlleva la exploración de los valores culturales, las imágenes, percepciones e ideas, y los estereotipos y mitos colectivos que se construyen socialmente bajo el paraguas de la interacción social. Dado que en este artículo se busca explorar estas imágenes y percepciones sobre la vejez en aquellos individuos que aún no viven dicha etapa, se hace uso de las percepciones y opiniones que se recopilan en encuestas con representación a nivel nacional para mostrar el desconocimiento de los procesos y la situación de la vejez, por lo que el análisis realizado deja fuera los elementos más finos de los significados de la vejez, como la influencia al respecto de los valores culturales, los símbolos y las costumbres. A continuación, se presenta dicho análisis.

\section{La vejez significada por adultos y jóvenes mexicanos en el siglo XXI}

Con la finalidad de alcanzar una primera exploración de los significados y representaciones sobre la vejez en los jóvenes, como ya se dijo, se hace uso de las percepciones y opiniones recopiladas en la ENE (Gutiérrez Robledo y Giraldo Rodríguez, 2015). Esta encuesta, interpretada por destacados especialistas en la materia, forma parte del proyecto Los Mexicanos Vistos por sí Mismos, con el que la Universidad 
Nacional Autónoma de México (UNAM) promueve el conocimiento de la sociedad mexicana a partir de sus opiniones y percepciones sobre diversos temas, como la constitución y las instituciones judiciales, pero también la familia y el mercado laboral, la globalización y las nuevas tecnologías de la información.

La colección dentro de la que se enmarca la ENE suma veintisiete ejemplares, cada uno de distinta temática. Como parte del tema que trata, la ENE inserta una batería de preguntas sobre la vejez y los procesos de envejecimiento. La encuesta fue levantada en una muestra de 1200 sujetos, de la que se han seleccionado para el presente estudio 1076 que aún no llegan a los sesenta años de edad. Esta submuestra, de más del $80 \%$ de la muestra original, se compone de un $47 \%$ hombres y un $53 \%$ mujeres.

Debe señalarse que la información recopilada en la ENE forma parte de la poca información que existe sistematizada y organizada a nivel nacional respecto de las opiniones sobre la vejez, las personas mayores y el proceso de envejecimiento, por lo que la encuesta constituye en sí misma una iniciativa pionera muy valiosa que da una visión de la vejez en un momento, sobre todo de aquellos que no son personas mayores.

Debe considerarse que los datos que se presentan en la presente investigación fueron procesados de las preguntas directamente reportadas en la ENE y que se encuentran en la página web del estudio a cargo de la UNAM, ${ }^{4}$ por lo tanto, son diferentes a los reportados en el libro de Gutiérrez Robledo y Giraldo Rodríguez (2015), que contiene los primeros resultados oficiales de la encuesta en general. En la presentación y análisis de los resultados que se hace a continuación, por tanto, se hace referencia a la encuesta antes que al libro de dichos autores.

4. Las bases de datos, el libro y la metodología están disponibles en y fueron tomados de: http://www.losmexicanos.unam.mx/envejecimiento/index.html 


\section{I. La vejez: debilidad, experiencia y vulnerabilidad}

$\mathrm{Al}$ igual que sucede en otros países en desarrollo, en México, la población suele conformar imaginarios y representaciones cargados de aspectos negativos de lo que se vive en la vejez y de quiénes son las personas mayores. Los datos analizados de la ENE muestran que, de manera general, los mexicanos consideran que la vejez es una etapa en la que las personas tienen un gran deterioro físico y mental, y poca productividad y utilidad para la sociedad (Agudelo, 2015, p. 32). Esto es interesante porque si bien algunas de estas características forman parte de esta etapa de la vida, no son las únicas que definen la vida de los individuos que se encuentran en ella.

Entonces, siguiendo la teoría de las representaciones sociales, primero se puede observar la imagen que socialmente se forma alrededor de la vida de las personas mayores en México: la mayoría de los jóvenes y adultos de entre dieciocho y cincuenta y nueve años define a las personas mayores por una condición de la edad biológica, la vejez o el ser viejo, que implica únicamente que el tiempo biológico, medido en años, ha tenido un curso.

Esta imagen se obtuvo a través de una asociación de palabras solicitada en la ENE, ${ }^{5}$ la cual pide asociar la palabra adulto mayor con otra. $\mathrm{Al}$ respecto, las palabras más frecuentes fueron viejo / viejito y anciano/ancianito. Llama la atención, además, el uso de diminutivos, que remiten a una visión de infantilidad o vulnerabilidad adjudicada a las personas mayores, aunque también pueden hacer referencia a cierto respeto y trato especial, que culturalmente se ha aprendido a expresar con diminutivos. No hubo diferencias entre los rangos de edad de los encuestados que respondieron como primera asociación viejitos o anciano, es

5. La pregunta seleccionada de la ENE para esta parte del análisis fue "Con la palabra maíz, yo asocio comida, mercado, animales. Dígame, por favor, tres palabras que asocie con la palabra adulto mayor". 
decir, tanto los de dieciocho años como los que están cerca de los sesenta presentaron la misma proporción en dicha respuesta.

Además de la edad biológica, que se relaciona con el paso del tiempo, también se define a las personas mayores a partir de la edad fisiológica, que implica a su vez el cambio de las condiciones del cuerpo humano con el paso del tiempo (Neugarten, 1999). Quizá por ello, algunas otras asociaciones en la misma pregunta correspondieron a palabras como enfermedad, canas y arrugas, que describen el deterioro del cuerpo en el paso del tiempo en la edad fisiológica.

Dentro de este grupo de relaciones, y como se observa en la Figura 1, los adultos de entre treinta y cinco y cincuenta y nueve años, es decir, más cercanos a la vejez, y en una proporción mayor que los encuestados de entre dieciocho y veinticuatro años, ligaron esta etapa de vida a la palabra experiencia, que alude a una capacidad desarrollada a partir del curso de la vida y no al cuerpo físico. 
Percepciones, imágenes y opiniones sobre la vejez desde la mirada de los adultos y jóvenes en México

Figura 1. Asociación con la palabra adulto mayor (porcentajes)

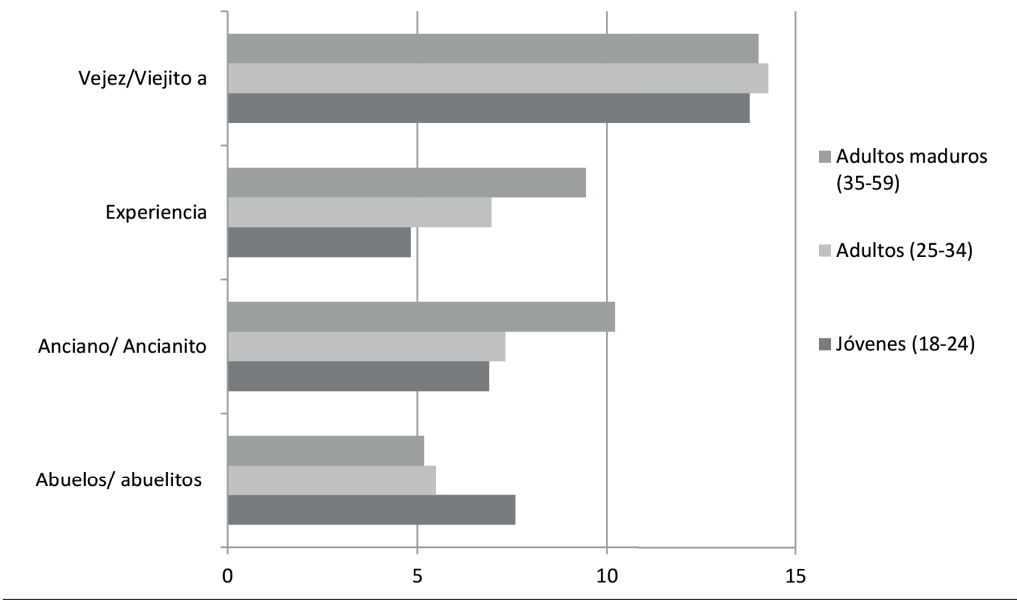

Fuente: elaboración propia con datos de la ENE. Se utiliza la submuestra de jóvenes y adultos (dieciocho a cincuenta y nueve años).

En conjunto con las imágenes sobre la vejez, explorar las percepciones sociales permite conocer también con qué patrones es pensada. $\mathrm{Al}$ respecto, los adultos encuestados señalaron creer que la vejez comienza a los setenta años como edad biológica, ${ }^{6}$ aunque al considerarse la edad fisiológica surgieron contrastes sobre las condiciones de definición de los límites de la etapa: para la mayoría de los entrevistados en la submuestra, la vejez comienza cuando una persona necesita ayuda para la mayoría de las actividades cotidianas o cuando su movilidad es reducida o desaparece, es decir, cuando adquiere un grado de dependencia considerable (70\% de los entrevistados). ${ }^{7}$ Además de esas dos opciones mayoritariamente elegidas, la encuesta incluía como posibles respuestas: 1) empieza a perder la memoria, 2) se adapta menos a los cambios, 3) se aísla de la sociedad,

6. Este dato se obtuvo de la pregunta de la ENE "¿A qué edad piensa que una persona debe de considerarse vieja?".

7. La pregunta concreta de la ENE era "Según su opinión, ¿una persona se puede considerar vieja cuando...?". 
4) disminuye las actividades productivas, 5) obtiene menos dinero de su trabajo, y 6) tiene más tiempo para sí misma.

Resulta interesante que a pesar de que tener más tiempo para sí mismos es una característica que muchas de las personas mayores reconocen como propia de sus vidas y dicen valorar, pocos de los encuestados la consideraron como opción primera de respuesta. Estas percepciones fueron muy parecidas entre grupos de edad y género. ${ }^{8}$

Otras percepciones de los jóvenes y adultos sobre la vejez dejan ver que los estereotipos sobre y comparaciones con otras etapas de la vida inciden también en el significado de la vejez y la vida de las personas mayores: la mayoría (34\%) de los adultos y jóvenes del país consideró que los sujetos de esta población se comportan como niños y se irritan con facilidad. Un porcentaje similar (30\%) estuvo de acuerdo con la frase de que los adultos mayores pierden el interés por las cosas. Por otro lado, afirmaciones como los adultos mayores son menos productivos tuvieron un $20 \%$ de acuerdo entre los encuestados, aunque generaron un similar $23 \%$ de desacuerdo (ver: Figura 2). ${ }^{9}$

8. Es necesario destacar que la pregunta de la encuesta inicialmente encasilla las respuestas posibles en definiciones considerables dificiles sobre la etapa de vida que aborda (pérdida de memoria, falta de movilidad física, aislamiento social, etc.),y utiliza pocas opciones para describir condiciones más positivas. Esto puede indicar estereotipos sobre el tema existentes desde el propio análisis científico-estadístico. 9. Pregunta de la ENE: "iY qué tan de acuerdo o en desacuerdo está usted con las siguientes frases? Las opciones son: A medida que nos hacemos mayores, perdemos el interés por las cosas/Las personas mayores son como niños/Las personas mayores se irritan con facilidad/Las personas mayores tienen menos capacidades para resolver los problemas/Los jóvenes trabajan mejor que los mayores/Los adultos mayores son menos productivos".

\section{8}


Percepciones, imágenes y opiniones sobre la vejez desde la mirada de los adultos y jóvenes en México

Figura 2. Porcentaje de respuesta muy de acuerdo

a pregunta sobre características de adultos mayores

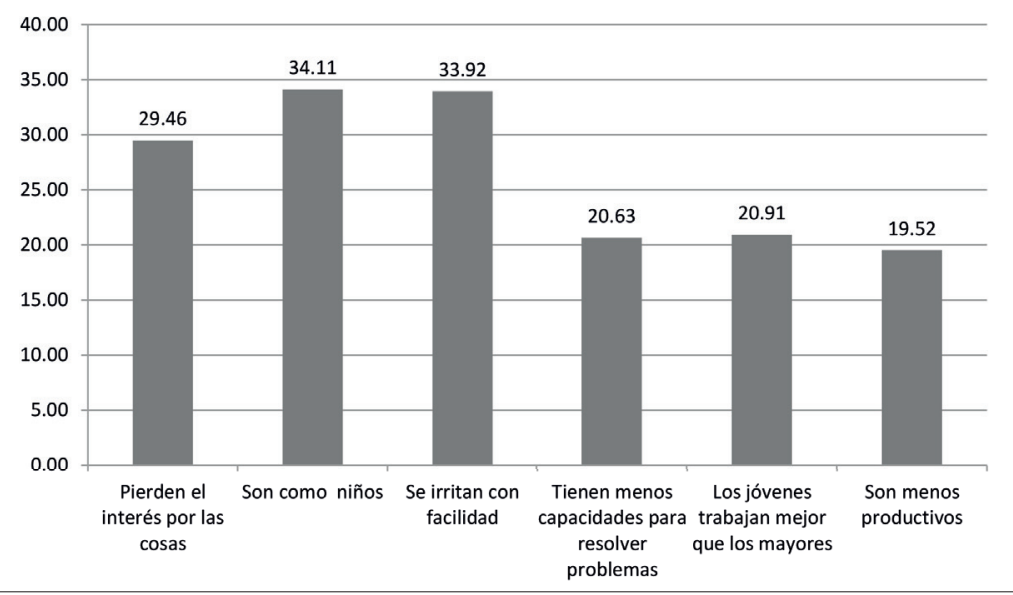

Nota: debido a que cada columna de esta gráfica es parte de un conjunto de respuestas que van de muy en desacuerdo a muy de acuerdo, la suma de las aquí presentadas no alcanza el 100\%, pues únicamente se presenta el porcentaje de la respuesta muy de acuerdo.

Fuente: elaboración propia con datos de la ENE. Se presenta la submuestra de jóvenes y adultos (dieciocho a cincuenta y nueve años).

Por otro lado, hay que destacar que los jóvenes aprecian y son conscientes del trabajo realizado por las personas mayores: sólo el 20\% de la muestra consideró que es menor el trabajo de los adultos mayores cuando se compara con el de los jóvenes, mientras que el $80 \%$ consideró que no es verdad que las personas mayores ya no sean productivas, lo cual es congruente con los estudios y valoraciones sobre las contribuciones sociales y económicas de la población envejecida.

En ese sentido, algunos estudios (Skirbekk, 2008) han mostrado que los seres humanos en edades avanzadas pueden trabajar en actividades que no requieren de gran fuerza física y sí de habilidades sociales, como el lenguaje, y en las cuales la experiencia que ya adquirieron es muy 
necesaria. Por lo tanto, las políticas públicas de empleo y los sistemas económicos en los contextos actuales deberán comenzar a pensar en la diversificación de las características del empleo que permita aprovechar las habilidades y capacidades de la población sin tomar en cuenta la edad (Skirbekk, 2008). Probablemente, nuevas ideas sobre la población mayor y la vejez serían desarrolladas si las condiciones de dicha población mejoraran en cuanto a trabajos mejor remunerados y en condiciones adecuadas.

Precisamente, sobre la colaboración de los adultos mayores en las dinámicas sociales y familiares, en la ENE se preguntó ¿qué tanto considera que los adultos mayores contribuyen en las siguientes actividades?, con las siguientes opciones para asignación de valor: 1) cuidado de nietos, 2) apoyo económico a sus familias, 3) compradores de bienes y servicios, 4) cuidado de familiares enfermos, y 5) cuidado de personas con discapacidad, como trabajadores pagados y como voluntarios.

La asignación de respuestas se valoró en una escala de nada a mucho. Mayoritariamente, los encuestados asignaron mucho al cuidado de nietos, seguido de la contribución económica directa a las familias y, en tercer lugar, del apoyo voluntario en diversas actividades. Esto llama la atención porque, sin duda, existe el conocimiento en la población sobre las tareas en las que colaboran las personas mayores, a pesar de la señalada movilidad reducida o las dificultades propias de la edad fisiológica avanzada que también los mismos encuestados relacionan con la vejez.

Sin embargo, haría falta preguntar si la población joven hace algún cálculo sobre los montos de dinero que representan estas actividades, los costos de una niñera o enfermera para la familia, por ejemplo, lo que generaría una medición de la colaboración de las personas mayores a sus familias y sociedad. Al mismo tiempo, esto delata la pobre valoración de las actividades hechas y requeridas por los seres 
humanos, como pasa con el trabajo femenino de cuidados, de acompañamiento, de consejería y de manejo del hogar, cuya falta de remuneración desdibuja su utilidad.

Figura 3. Porcentajes de respuesta mucho a pregunta sobre contribución de adultos mayores a actividades

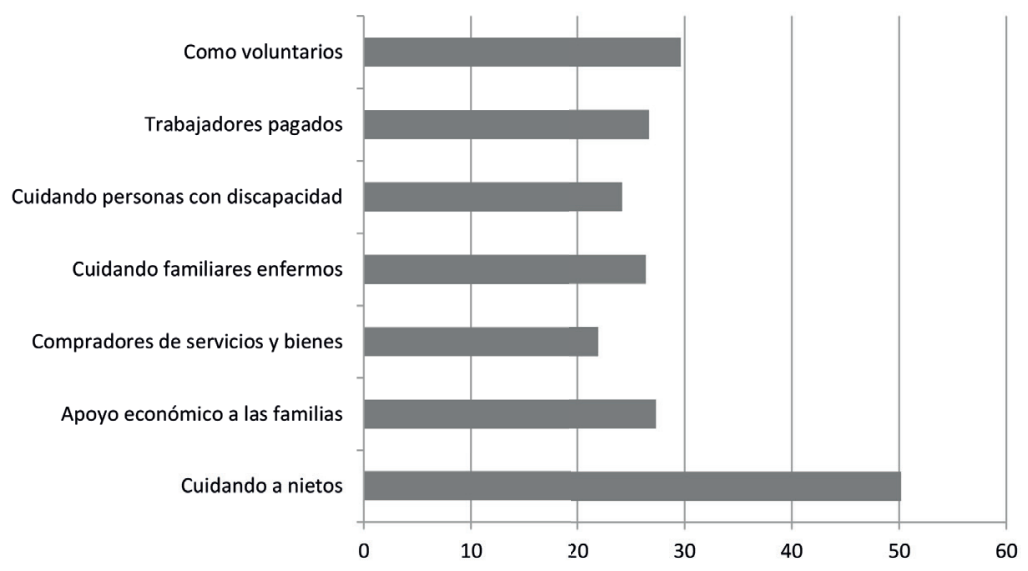

Nota: debido a que cada columna de esta gráfica es parte de un conjunto de respuestas que van de nada a mucho, la suma de las aquí presentadas no alcanza el 100\%, pues únicamente se presenta el porcentaje de la respuesta mucho.

Fuente: elaboración propia con datos de la ENE. Submuestra de jóvenes y adultos (dieciocho a cincuenta y nueve años).

De la mano de la valoración de la experiencia de las personas mayores, se observa que los adultos y jóvenes consideraron (57\%) que las opiniones de los adultos mayores deben ser tomadas en cuenta de manera amplia en la toma de decisiones familiares. ${ }^{10}$ Sin embargo, una pregunta que daría más información de prácticas sociales específicas sería qué tanto esos mismos encuestados toman en cuenta las

I0. Pregunta de la ENE:“¿Qué tanto piensa usted que deberían tomarse en cuenta las opiniones de los adultos mayores en las decisiones familiares?, con opciones de respuesta: mucho/poco/nada/depende (esperada)". 
opiniones de los adultos mayores en situaciones precisas dentro de sus familias.

Hasta este momento, es posible decir que se observan algunas imágenes contradictorias sobre la vejez: por un lado, se relaciona con el deterioro del cuerpo y la debilidad, y por otro, se vincula a la experiencia y el trabajo en dicha etapa de vida como cuestiones valoradas.

Para complementar estas imágenes, se han seleccionado otras preguntas, en específico sobre el papel de la ciudadanía y el Estado en el cuidado y mejora de la calidad de vida de las personas mayores.

$\mathrm{Al}$ respecto, la responsabilidad de la ciudadanía en la mejora de las condiciones de vida de los adultos mayores es señalada por los jóvenes y adultos mexicanos encuestados: la mayoría de ellos (50\%) dijo estar muy de acuerdo con que los impuestos pagados al Gobierno se utilicen en mejorar dichas condiciones; ${ }^{11}$ al mismo tiempo, el envejecimiento poblacional fue señalado como un tema muy preocupante para el país.

No obstante, al ser interrogados sobre políticas públicas específicas para ayudar a esta población, los encuestados de la submuestra opinaron sobre formas que valoran poco la reinserción y diversidad laboral para los adultos mayores, así como la sensibilización de la población en general, por lo que sus respuestas se dirigieron más bien a la ayuda inmediata (despensas, servicios de salud) y económica (asistencialismo), principalmente. Esto es de esperarse pues son las formas de políticas públicas más frecuentemente implementadas por los Gobiernos nacionales y estatales, aunque este tipo de atención coloca a los adultos mayores como sujetos pasivos y objeto de ayuda directa, y no como

I I. La pregunta específica de la ENE fue:" ¿Y qué tan de acuerdo o en desacuerdo está usted con las siguientes frases?". Se tomaron para el análisis las respuestas a la opción "Los impuestos que pagamos deben ser utilizados para dar a los mayores un mejor nivel de vida". 
Percepciones, imágenes y opiniones sobre la vejez desde la mirada de los adultos y jóvenes en México

propulsores de proyectos y cambios, papel que ya va adquiriendo alguna proporción de ellos.

La Figura 4 presenta las tres áreas de política pública más y menos relevantes respecto a la vejez señaladas por los encuestados.

Figura 4. Políticas públicas de ayuda

a los adultos mayores (porcentajes)

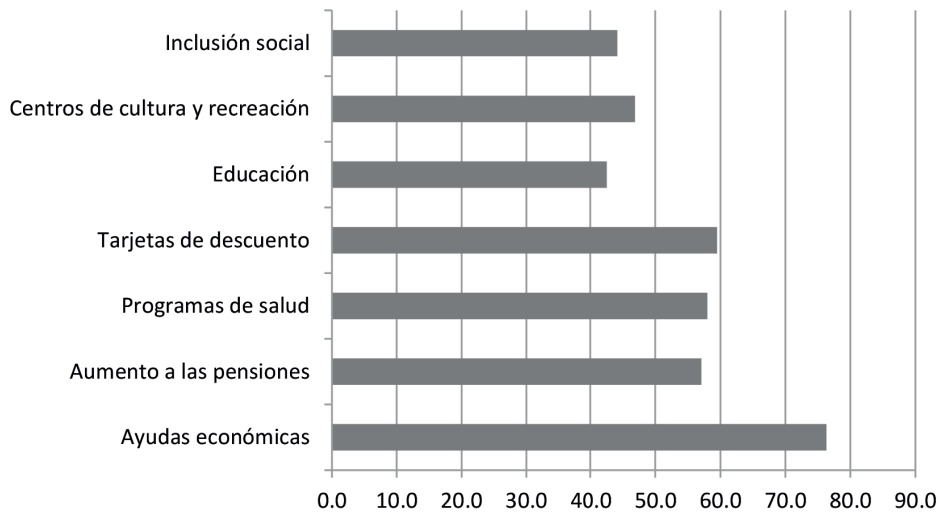

Nota: debido a que cada columna de esta gráfica es parte de un conjunto de respuestas que van de nada importantes a muy importantes, la suma de las aquí presentadas no alcanza el $100 \%$, pues únicamente se presenta el porcentaje de la respuesta muy importantes.

Fuente: elaboración propia con datos de la ENE. Submuestra de jóvenes y adultos (dieciocho a cincuenta y nueve años).

Como se puede ver en dicha figura, las tres políticas públicas señaladas como más relevantes fueron las ayudas económicas, los programas de salud y las tarjetas de descuentos del Instituto Nacional de las Personas Adultas Mayores (Inapam). Las respuestas menos apoyadas como muy importantes fueron la educación, los centros de cultura y recreación y los programas de inclusión social. ${ }^{12}$

I2. La pregunta de la ENE fue:"En una escala de 0 al I0, como en la escuela, donde 0 es nada importante y 10 es muy importante, según su opinión, ¿qué tan importantes 
Estas opiniones muestran que las percepciones de las problemáticas a atender siguen estando focalizadas en las condiciones económicas de las personas mayores y en menor medida en sus condiciones sociales, psicológicas y familiares, aunque, como se dijo antes, estas últimas condiciones sean las que dicho grupo poblacional más valora. Nuevamente, este comportamiento responde a la posición que adoptan los Gobiernos y las políticas públicas, lo cual influye en el conocimiento y opiniones de la población al respecto de cómo tratar la problemática social.

Aunado a ello, la mayoría de los jóvenes y adultos considera que los cuidados diarios de las personas mayores corresponden a sus familias, y no tanto al Estado. A la pregunta Por lo que usted piensa, ¿de quién es la principal responsabilidad en la atención de los adultos mayores en nuestro pais? ${ }^{13}$ el $62 \%$ respondió que de la familia y sólo el 17\% responsabilizó al Estado; únicamente el 15\% consideró que la atención a los adultos mayores es responsabilidad de todos (Figura 5).

En una pregunta similar que evaluaba acuerdo/desacuerdo con diferentes frases, se volvió a opinar que la mayor responsabilidad de la atención y cuidados de las personas mayores es de las familias, con los hijos como específicos cuidadores de los padres en esta etapa. Si bien hay una razón de reciprocidad en estas ideas sobre la responsabilidad de las personas mayores que requieren cuidado, también existen condiciones de las nuevas socie-

son las siguientes políticas públicas para ayudar a los adultos mayores? Las opciones son: ayudas económicas/flexibilizar el horario de trabajo de los que cuidan a los ancianos/programas de inserción laboral/educación/aumento de las pensiones/ centros de cultura y recreación/educación intercultural para adultos mayores indígenas/programas de salud/programas de acondicionamiento físico/servicios psicológicos/tarjetas de descuento (Inapam)/creación de asilos de calidad para atención/sensibilidad general de la población/capacitación para el cuidado de adultos mayores".

13. Las opciones de respuesta fueron: el Gobierno/la familia/los mismos adultos/ todos (esperada)/otra (esperada). 
dades que pueden impedir el camino de la reciprocidad y crear espacios de maltrato y abuso, por lo que debe haber alternativas para aquellas personas mayores que no cuenten con un apoyo familiar.

Junto a esta visión de la familia como responsable de la persona mayor, algunos estudios han mostrado cómo las familias están haciendo un gran esfuerzo por sostenerse y apoyar a la población adulta mayor, la mayoría a través de intercambios intergeneracionales de bienes y servicios entre padres, hijos y nietos a partir de los cuales el hijo sostiene económicamente a su padre mientras este cuide a sus nietos durante las horas laborales y se encargue de su educación, por ejemplo (Tamez y Ribeiro, 2014; Herrera y Fernández, 2013).

Este tipo de relaciones de intercambio, que no son propiamente monetarias, plantean la interrogante de qué sucedería con los adultos mayores si cayeran en mayor dependencia por sus condiciones de salud y movilidad física y eso les impidiera seguir intercambiando bienes y servicios con la familia. ¿Serían todos ellos sostenidos por sus familias?, ¿tendrían las familias las capacidades para hacerlo?

Por otro lado, existe una proporción de adultos mayores que, sin ser la mayoría, vive sola o con personas que no son sus familiares, no convive con estos o la abandonaron, por lo que es imposible que esté siendo apoyada económica, psicológica, física o socialmente por ellos, dado lo cual cabe preguntar ¿quién podría o debería apoyarla? 
Figura 5. Actores responsables de la atención a los adultos mayores

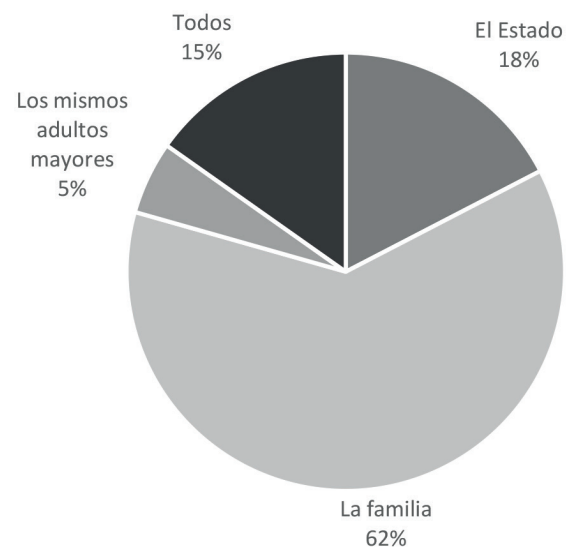

Fuente: elaboración propia con datos de la ENE. Submuestra de jóvenes $\mathrm{y}$ adultos (dieciocho a cincuenta y nueve años).

Por otro lado, las opiniones sobre el papel de los adultos mayores en el medio laboral remunerado son positivas. La mayoría (77\%) de los adultos y jóvenes opinó que las personas mayores deberían tener los mismos derechos de acceso al trabajo que los jóvenes, y que en una empresa el papel de las personas podría ser valioso también después de los sesenta y cinco años (70\%). Asimismo, cuando se cuestiona sobre la posibilidad de que los adultos mayores dejen su lugar de trabajo a los jóvenes, la mayoría considera que esto no es correcto (50\%) (Figura 6). ${ }^{14}$ Estas opiniones describen una visión de las personas mayores como productivas económica y socialmente que se distancia de la idea que persiste de que son como niños y se irritan rápidamente.

14. La pregunta para ambos datos fue:"Dígame, por favor, si comparte o no comparte las siguientes afirmaciones (leer opciones). Las opciones son: es justo que los adultos mayores tengan los mismos derechos de los jóvenes de acceder al trabajo/ los adultos mayores deberían dejar su lugar a los jóvenes una vez cumplidos los sesenta y cinco años/en una empresa, el papel de los ancianos podría ser valioso también después de los sesenta y cinco años". 
Figura 6. Porcentajes de muy de acuerdo con diversas afirmaciones

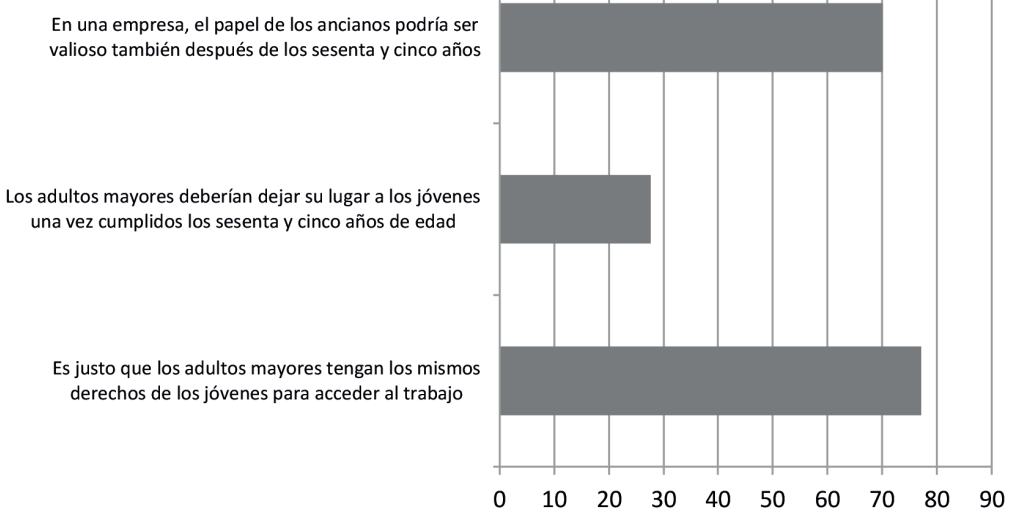

Nota: debido a que cada columna de esta gráfica es parte de un conjunto de respuestas que van de muy en desacuerdo a muy de acuerdo, la suma de las aquí presentadas no alcanza el 100\%, pues únicamente se presenta el porcentaje de la respuesta muy de acuerdo.

Fuente: elaboración propia con datos de la EnE. Submuestra de jóvenes y adultos (dieciocho a cincuenta y nueve años).

Estas opiniones sobre la importancia de la productividad laboral son relevantes también porque al ser una población en crecimiento es necesario tomarla en cuenta en los planes y políticas públicas de crecimiento y desarrollo económico, en los cuales resulta crucial, como lo han señalado diversos estudios sobre Europa que consideran imprescindible incluir a los adultos mayores como una población a la que no sólo hay que atender y asistir, sino también integrar a la reproducción social, económica y política (Mordini y Mantovani, 2010). De otra forma, no sólo aumentará la exclusión de los adultos mayores y se reflejará en pobreza, abandono o enfermedad, sino que también el resto de la sociedad tendrá insuficiencia para sostenerse. 
Por otro lado, es en el ámbito laboral donde más discriminación sufre este tipo de población, precisamente porque no es contratada o se le descarta en los recortes de personal.

Finalmente, observando las razones por las que los jóvenes y adultos consideran necesario ayudar a los adultos mayores, se observan nuevamente percepciones poco empáticas con la problemática: el $60 \%$ considera que es un deber moral ayudarlos y otro $20 \%$ lo hace por simpatía. Una minoría considera importante ayudarlos porque es de su propio interés o de interés para toda la sociedad (Figura 7). ${ }^{15}$

Figura 7. Razones para ayudar a los adultos mayores

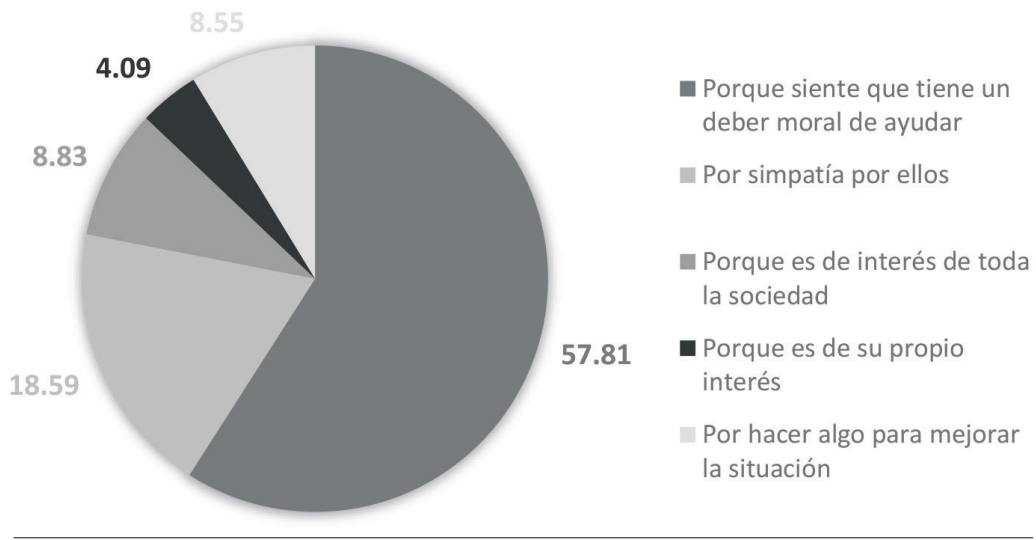

Fuente: elaboración propia con datos de la ENE. Submuestra de jóvenes $\mathrm{y}$ adultos (dieciocho a cincuenta y nueve años).

Hasta aquí, se han descrito algunas de las percepciones de los jóvenes y adultos al respecto de las personas mayores y la vejez que muestran una opinión de respeto y necesidades de cuidados familiares, acompañada de percepciones sobre

15. La pregunta de la ENE fue:"Pueden existir distintas razones para ayudar a los ancianos. De las siguientes, podría decirme por favor, ¿cuáles son las tres más importantes para usted? Las opciones son: Porque siente que tiene un deber moral de ayudar/Porque tiene simpatía por ellos/Porque es de interés de toda la sociedad/Porque es en su propio interés/Para hacer algo por mejorar su situación". 
vulnerabilidad y comportamientos infantiles. Aunque las imágenes de la vejez como una condición física determinada por la edad sostienen algunos estereotipos, como que las personas mayores ya no pueden hacer nada o son poco útiles, las opiniones y percepciones sobre su papel social y familiar son distintas: se reconoce que muchas personas mayores siguen colaborando en el ámbito familiar o trabajando en condiciones discriminatorias y, por ello, también se señala que deben ser sujetos de derechos y programas públicos especiales.

Ahora bien, es probable que esta etapa de la vida sea estereotipada con características negativas porque muchas de las condiciones de vida de los adultos mayores no son dignas ni deseables. Además del deterioro físico del cuerpo por la edad, las condiciones económicas y de acceso a servicios de salud no son halagadoras. Se ha dicho ya que una buena parte de los adultos mayores de sesenta y cinco años en México vive en condiciones de pobreza; que más del $60 \%$ de esta población se provee de las ayudas familiares porque sus ingresos son muy reducidos; que las condiciones físicas se deterioran al grado de generar una dependencia de los otros, que crece más conforme se avanza en la edad; y que las estadísticas de abandono, maltrato y discriminación también son altas, por lo que a los ojos de los otros hay varias condiciones en la vejez poco deseables para cualquier ser humano.

\section{Reflexiones finales}

Esta investigación ha tenido como objetivo conocer y explorar las percepciones, imágenes, y opiniones de la población no envejecida sobre la vejez y las personas mayores en México. Como fin último, se ha buscado contrastar los estereotipos predominantes con algunas características de la vida de las personas mayores y poner en el debate que las 
percepciones e imágenes negativas abonan a los procesos de discriminación y maltrato contra la población mayor. Todo ello es evidencia de una ausencia de conocimiento e información sobre esta población y sus vidas, así como una ausencia de la inclusión de todos los actores sociales en estos procesos de envejecimiento.

Así, se exploraron algunas de estas percepciones e imágenes a partir de las generalidades que otorga la ENE de 2015. Desde sus datos, se describieron las percepciones y opiniones de la población que aún no llega a la vejez, con edades de los dieciocho a cincuenta y nueve años de edad.

Los hallazgos muestran procesos muy interesantes. En primer lugar, se señala que, pese a que la población mexicana está envejeciendo, las percepciones y opiniones sobre la vejez apuntan al desconocimiento de las implicaciones de esta etapa y están cargadas hacia la observación del fenómeno como una etapa separada y última de la vida, cuando la realidad ha mostrado que las capacidades humanas van más allá de la tercera edad hacia una cuarta o quinta edad, lo que significa que no hay un término inmediato de la vida. La noción del envejecimiento como un proceso no aparece entre las ideas y percepciones de los jóvenes y adultos.

Respecto a las asociaciones de palabras de los jóvenes adultos encuestados, se observan definiciones ligadas a las condiciones físicas y biológicas de las personas mayores, tales como debilidad y cansancio, aunadas a la percepción de una imagen infantil y de vulnerabilidad. Por otro lado, cuando se define por qué es importante ayudar a las personas mayores, los adultos y jóvenes consideran que se trata de un deber moral y no de una empatía humana o fenómeno social que ataña a todos, por estar todos los sujetos en proceso de envejecimiento.

En cuanto a la responsabilidad del cuidado y atención de esta población, es indudable que la mayoría de los jóvenes y adultos piensa que es necesario que las personas mayores 
reciban atenciones adecuadas y universales, aunque cuando se pregunta por quién debe proveerlas es frecuente que se hable más de la familia que de la sociedad en su conjunto o el Estado. Esto es de especial importancia porque en otros contextos se ha comenzado a observar que las nuevas formas de familia y dinámicas familiares y económicas hacen muy difícil que aquellas se hagan cargo de sus adultos mayores, de modo que el papel del Estado y la sociedad es fundamental a este respecto.

Finalmente, el panorama general muestra algunas contradicciones. Mientras las condiciones de los adultos mayores mejoran lentamente en el país, las percepciones y significados sobre la vejez se ubican frecuentemente sobre la debilidad y el deterioro físico. Mientras las opiniones sociales muestran que los adultos mayores que pueden trabajar deberían tener opciones para hacerlo, es decir, que no es adecuada la discriminación por edad, casi todos los adultos mayores del país han sido discriminados en el empleo por tener una edad avanzada. Mientras se asegura que las familias son las principales responsables del cuidado de los adultos mayores, las estimaciones de maltrato dentro de estas para esta población son altas. Debido a que se piensa en este proceso como un problema individual y lejano a la propia realidad, se piensa que ayudar y ocuparse de la población a él vinculado es más un deber moral con el que hay que cumplir y no un fenómeno de interés social que influye en todos y que alcanzará a todos en México. Se observa que, en efecto, hay poco conocimiento y comprensión de las condiciones de las personas mayores, por lo que se forman estereotipos y referencias que llevan a un trato inadecuado hacia esta población. 
Bibliografía
Agudelo, M. (20I5). Las percepciones de los mexicanos sobre las personas adultas mayores. En L. M. Gutiérrez Robledo, y L. Giraldo Rodríguez (coords.), Realidades y expectativas frente a la nueva vejez. Encuesta Nacional de Envejecimiento (pp. 29-5I). México: Instituto de Investigaciones Jurídicas, UNAM. Recuperado de http://www. losmexicanos.unam.mx/envejecimiento/index.html

Anderson, G. F., y Hussey, P. S. (2000). Population aging: A comparison among industrialized countries. Health affairs, 19(3), I91-203. doi https://doi.org/10.1377/ hlthaff.19.3.191

Castoriadis, C. (1997). El imaginario social instituyente. Zona erógena, (35), I-9. Recuperado de http://www. ubiobio.cl/miweb/webfile/media/267/Castoriadis\%20 Cornelius\%20-\%20El\%20Imaginario\%20Social\%20Instituyente.pdf

Cathalifaud, M. A.,Thumala, D., Urquiza, A.,y Ojeda, A. (2007). La vejez desde la mirada de los jóvenes chilenos: estudio exploratorio. Última década,(27),75-9I. Recuperado de https://scielo.conicyt.cl/pdf/udecada/v15n27/art05.pdf

Comisión Económica para América Latina y el Caribe (20l I). Los derechos de las personas mayores. Materiales de estudio y divulgación. Chile: ONU-UNFRA-ASDI. Recuperado de https://www.cepal.org/celade/noticias/documentosdetrabajo/2/43682/modulo_I.pdf

Consejo Nacional de Población (20I I). Diagnóstico sociodemográfico del envejecimiento en México. Serie Documentos técnicos. México: conapo. Recuperado de http://www. conapo.gob.mx/es/CONAPO/Diagnostico_socio_ demografico_del_envejecimiento_en_Mexico

Consejo Nacional para Prevenir la Discriminación (2005). Encuesta Nacional sobre Discriminación, ENADIS. México: Conapred. Recuperado de https://www.conapred. org. $\mathrm{mx} /$ index.php? contenido=pagina\&id $=424 \& i d$ opcion $=4366 \&$ op $=436$ 
Consejo Nacional para Prevenir la Discriminación (2010). Bibliografía Encuesta Nacional sobre Discriminación, ENADIS. México: Conapred. Recuperado de https://www.conapred. org. $\mathrm{mx} / \mathrm{index}$.php?contenido=pagina\&id=424\&id opcion $=4366 \&$ op $=436$

Fernández, M. C.,y Herrero, S. (2006). Maltrato en el anciano. Posibilidades de intervención desde la atención primaria. Atención primaria, 37(2), II3-1 I5. doi https://doi. org/I0.1 I 57/I 3083927

Gergen, K., y Gergen, M. (2000). The new aging: Self-construction and social values. En K. Schaie, y J. Hendricks (ed.), The evolution of the aging self, the societal impact on the aging process (pp. 28I-306). Nueva York: Springer.

Giurani, F., y Hasan, M. (2000). Abuse in Elderly People: the Granny Battering Revisited. Archives of Gerontology and Geriatrics, (31), 215-220. doi https://doi.org/10.1016/ S0I67-4943(00)00080-7

Giraldo, L. (2006). Malos tratos hacia las personas adultas mayores:una caracterización sociodemográfica en la Ciudad de México [tesis de maestría inédita]. El Colegio de México: México. Recuperado de http://colmex-primo. hosted.exlibrisgroup.com/primo_library/libweb/action/ search.do? mode=Basic\&vid=52COLMEX_INST\&tab=52colmex_tab_tes\&

Giraldo, L. (20I0). El maltrato a personas mayores: una mirada desde la perspectiva de género. Debate feminista, 42, I5 I-165. Recuperado de: http://debatefeminista.cieg. unam.mx/index.php/category/vol-42/

Gutiérrez Robledo, L. M., y Giraldo Rodríguez, L. (coords.) (20I5). Realidades y expectativas frente a la nueva vejez. Encuesta Nacional de Envejecimiento. México: Universidad Nacional Autónoma de México. Recuperado de http://www.losmexicanos.unam.mx/envejecimiento/ encuesta_nacional.html 
Ham, C.,y González, C. (2008). Discriminación en las edades avanzadas en México. Papeles de población, (55), 37-58. Recuperado de https://rppoblacion.uaemex.mx/article/ view/8596

Herrera, S., y Fernández, B. (2013). ¿Está disminuyendo la solidaridad intergeneracional en América Latina? Un estudio de las relaciones intergeneracionales de los hijos con los adultos mayores. En V. Montes de Oca (coord.), Envejecimiento en América Latina y el Caribe (pp. 27I-300). México: UNAM.

Huenchuan, S. (2006). Políticas de la vejez como mecanismo de promoción de los derechos de las personas mayores: algunos acercamientos teórico-conceptuales. Revista brasileira de ciências do envelhecimento humano, 3(2), 52-60. Recuperado de http://seer.upf.br/index.php/ rbceh/issue/view/ 12

Instituto Nacional de Estadística y Geografía (20 I0). Censo de Población y Vivienda 2010. Recuperado de https:// www.inegi.org.mx/programas/ccpv/20I0/

Instituto Nacional de Estadística y Geografía (20I5). Encuesta Intercensal, tabulados. Recuperado de https:// www.inegi.org.mx/programas/intercensal/20I5/default. html\#Tabulados

Kehl,W. S., y Fernández, J. M. (200I). La construcción social de la vejez. Cuadernos de trabajo social, (I4), I25-I6I. Recuperado de http://revistas.ucm.es/index.php/CUTS/ issue/view/CUTSOI0I I I/showToc

Levy, B., Ashman, O., y Dror, I. (2000). To be or not to be: Effects of Aging Stereotypes on the Will to Live. Omega, 40(3), 409-420. doi https://doi.org//0.2190/Y2GEBVYQ-NF0E-83VR

Mead, G. (1982). Espíritu, persona y sociedad desde el punto de vista del conductismo social. Barcelona: Paidós. 
Montes de Oca,V. (20I0). Pensar la vejez y el envejecimiento Bibliografía en el México contemporáneo. Renglones, (62), I59-I8I. Recuperado de http://hdl.handle.net/I I I 7/235

Montes de Oca,V. (20I3). La discriminación hacia la vejez en la Ciudad de México: contrastes sociopolíticos y jurídicos a nivel nacional y local. Perspectivas sociales, I5(19), 47-80. Recuperado de http://perspectivassociales.uanl. mx/index.php/pers

Moñivas, A. (1998). Representaciones de la vejez (modelos de disminución y de crecimiento). Anales de psicología, I4(I), 13-25. Recuperado de https://digitum.um.es/ xmlui/bitstream/I020 I/I0 I 40/I/Representaciones\%20 de\%20la\%20vejez\%20modelos\%20de\%20disminucion\%20y\%20de\%20crecimiento.pdf

Mora, M. (2002). La teoría de las representaciones sociales de Serge Moscovici.Athenea digital, (2), I -25. Recuperado de http://blues.uab.es/athenea/num2/Mora.pdf

Mordini, E., y Mantovani, E. (2010).Ageing in the Information Society. En E. Mordini, y P. De Hert (eds.), Ageing and Invisibility (Pp. 50-82). Ámsterdam: Ios Press.

Moscovici, S. (2000). Social Representations, Explorations in Social Psychology. Cambridge: Polity Press.

Muramatsu, N., y Akiyama, H. (20I I). Japan: Super-Aging Society Preparing for the Future. The Gerontologist, 5 I (4), 425-432. doi https://doi.org// 0.1093/geront/gnr067

Neugarten, D. (ed.) (1999). Los significados de la edad. España: Herder.

Neugarten, B. L., Moore J., y Lowe J. (1999). Normas de la edad, limitaciones de la edad y socialización de los adultos. En D. Neugarten (ed.), Los significados de la edad (pp. 47-58). España: Herder.

Rice, C. J., Löckenhoff, C. E., y Carstensen, L. L. (2002). En busca de independencia y productividad: cómo influyen las culturas occidentales en las explicaciones individuales y científicas del envejecimiento. Revista latinoamericana 
de psicología, 34(I), I33-I54. Recuperado de http://www. redalyc.org/articulo.oa?id=805342 I I

Rodríguez, V., et al. (20I I). Recursos económicos y calidad de vida en población mayor. Revista internacional de sociología, 69(I), 195-227. doi http://dx.doi.org// 0.3989/ ris.2009.1I.26

Rojo, P. F., y Fernández, M. G. (20I I). Calidad de vida y envejecimiento, la visión de los mayores sobre sus condiciones de vida. España: Fundación BBVA. Recuperado de http://hdl.handle.net/ / 026 I/76540

Ronzón Hernández, Z. (20|4). El lugar de la vejez en el discurso intergeneracional. En V. Montes de Oca (coord.), Vejez, salud y sexualidad en México. Aproximaciones disciplinarias desde perspectivas cuantitativas y cualitativas (PP. 287-334). México: Instituto de Investigaciones Sociales, UNAM.

Dionigi, R.A. (20I5). Stereotypes of Aging:Their Effects on the Health of Older Adults. Journal of Geriatrics, (20I5), I-9. doi https://doi.org/ I0.1 I55/20 I5/954027

Skirbekk,V. (2008).Age and Productivity Capacity: Descriptions, Causes and Policy Options. Ageing Horizons, (8), 4-12. Recuperado de http://pure.iiasa.ac.at/8588

Tamez, B., y Ribeiro, M. (20।4). La solidaridad familiar hacia los adultos mayores en Monterrey, Nuevo León. En V. Montes de Oca (coord.), Vejez, salud y sexualidad en México. Aproximaciones disciplinarias desde perspectivas cuantitativas y cualitativas (Pp. I53-206). México: Instituto de Investigaciones Sociales, UNAM.

Taylor, C. (2006). Imaginarios sociales modernos. España: Paidós Básica.

Villa, M., y Rivadeneira, L. (2000). El proceso de envejecimiento de América Latina y el Caribe: una expresión de la transición demográfica [conferencia presentada en el Encuentro Latinoamericano y Caribeño sobre Personas de Edad]. Seminarios y Conferencias CELADE, CEPAL:Santiago 
Percepciones, imágenes y opiniones sobre la vejez desde la mirada de los adultos y jóvenes en México

de Chile. Recuperado de https://repositorio.cepal.org/

Bibliografía bitstream/handle/ I I362/7 I55/SO I I 2 1062_es.pdf 